\title{
HUBUNGAN MOTIVASI KERJA DENGAN PERILAKU NELAYAN PADA USAHA PERIKANAN TANGKAP
}

\author{
(RELATIONSHIP OF MAKING MOTIVATION THE BEHAVIOR \\ OF THE FISHERMAN)
}

Helena Tatcher Pakpahan, Richard W. E. Lumintang, dan Djoko Susanto

\begin{abstract}
Community of fishermen is one of social segments who considered as having daily life worse than other social segments, such as farmers, factory labourers, etc. Certain efforts can be done to improve the level of life of the fishermen, i.e to increase their production of fish. The way which can be done is by improving the unit of productive assets so that it can increase motivation of the fishermen for better behavior. Recently fishermen are not able to go out from their miserable socio economic situation, mainly due to (a) bargaining position weakness, (b) lacking of capital, (c) low level of knowledge and skill, (d) lacking of supervision, (e) no guarantee of promising market. Based on those evidence it is worth to study the relationship between fishermen motivation and their behavior to increase production of fish.
\end{abstract}

Key Words: fishermen, behavior.

\section{Pendahuluan}

Indonesia dikaruniai lautan yang lebih luas dari daratan. Dua pertiga wilayah Indonesia adalah perairan laut yang terdiri dari laut pesisir, laut lepas, teluk dan selat. Luas wilayah laut termasuk didalamnya Zona Ekonomi Eksklusif mencapai $5,8 \mathrm{~km}^{2}$ atau sekitar $3 / 4$ dari luas keseluruhan wilayah Indonesia (Conyer, 1994: 124). Menurut Nikijuluw (2002: 1), selain sumber daya perairan Indonesia juga memiliki 17.508 pulau yang menjadikan Indonesia sebagai kepulauan yang besar di dunia. Hanya ada beberapa pulau besar seperti Jawa, Kalimantan, Sumatera, Sulawesi, Irian, dan Flores. Sisanya adalah pulau-pulau kecil yang memiliki sifat-sifat ekosistem yang khas.

Upaya yang dapat dilakukan untuk meningkatkan taraf hidup atau pendapatan nelayan tidak hanya bertumpu pada peningkatan produksi hasil tangkapan semata, tetapi mencakup seluruh aspek. Salah satu cara meningkatkan produksi adalah dengan mengusahakan unit penangkapan yang lebih produktif dalam jumlah dan hasil tangkapan. Unit penangkapan haruslah bersifat ekonomis, efisien dan sesuai dengan kondisi setempat dengan tidak merusak kelestarian sumberdaya perikanan dan lingkungan hidup yang didukung oleh pengembangan agroindustri, prasarana dan peningkatan kualitas tenaga kerja.

Nelayan pada umumnya terdiri dari masyarakat yang pendidikannya relatif rendah dan hidupnya miskin. Mereka bekerja pada juragan yang mempunyai kapal dan alat tangkap yang memadai untuk melakukan penangkapan ikan di laut. Kegiatan ditentukan oleh alam dan lingkungannya.

Kemampuan mereka dalam meningkatkan pendapatan, menghidupi keluarga serta membangun hari depan yang lebih baik sangat rendah. Mereka memiliki 
banyak kesulitan karena usaha penangkapan ikan yang mereka lakukan sangat bergantung pada alam dan lingkungan. Menurut Kusnadi (2004: 1) hanya sebahagian kecil golongan masyarakat nelayan yang kehidupannya makmur, seperti para pemilik payang (glatheh) atau purse seine (sleret).

Struktur masyarakat pesisir bawah nelayan memiliki kerawanan sosial yang tinggi disebabkan oleh dua hal. Pertama, masalah tekanan kemiskinan dan keterbatasan peluang kerja. Kedua, secara kultural (budaya) nelayan bersifat lebih terbuka dan temperamental karena masa-masa yang harus diwaspadai adalah ketika musim barat tiba.

Usaha penangkapan ikan dikenal dua musim, yaitu musim banyak ikan (musim timur) dan musim sedikit ikan (musim barat) yang lebih sering dikenal dengan musim paceklik. Bila musim ikan datang (musim timur), mereka baru bisa berusaha, nelayan tidak perlu mengeluarkan energi yang banyak. Hanya dengan usaha yang relatif kecil, mereka sudah mendapatkan ikan, tetapi mereka kurang kuat (tanpa motor tempel). Banyak yang tidak mampu melakukan penangkapan ikan, padahal kebutuhan rumah tangga harus terpenuhi dari hasil menangkap ikan.

Terhadap kesulitan seperti itu, juragan memberikan bantuan barang-barang konsumsi (pangan) dengan perjanjian bahwa sebagian hasil tangkapan diserahkan kepada juragan sebagai pelunasan bantuan yang telah diberikan. Nelayan merasa ditolong dari kesulitan yang dihadapi. Mereka cenderung menyetujui pendapat juragan, sehingga di antara nelayan-juragan tumbuh sikap saling tergantung. Akan tetapi, bila musim tidak memungkinkan untuk melaut, nelayan harus mengeluarkan tenaga ekstra untuk mendapatkan ikan, bahkan menunggu musim penangkapan ikan berikutnya dan hidup seadanya. Apabila musim penangkapan ikan belum tiba, nelayan berdiam diri di rumah dan menunggu musim berikutnya. Padahal, keluarga membutuhkan biaya untuk hidup. Akibatnya, mereka terdorong menjual barang yang dimiliki guna memenuhi tuntutan hidup.
Kehidupan miskin yang dialami sebagian besar nelayan di Indonesia menyebabkan "bargaining position" mereka sangat lemah. Mereka merasa 'terisolasi', baik secara sosial, ekonomi maupun politik. Secara sosial, mereka tetap teridentifikasi sebagai masyarakat marginal (terpinggirkan) dan tidak memiliki modal sosial memadai untuk bersaing dengan nelayan-nelayan kapitalis atau nelayan-nelayan pengusaha perikanan. Kalaupun ada HNSI (Himpunan Nelayan Seluruh Indonesia) sebagai wadah, anggotanya tidak melibatkan para nelayan kecil, tetapi nelayan-nelayan kapitalis yang memiliki modal besar dan "bargaining position" tinggi dengan pemerintah atau berbagai stakeholders lainnya.

Secara ekonomis pendapatan sangat kecil dan hanya mampu menghidupi keluarganya untuk sehari; sedangkan secara politik mereka tetap tertindas oleh struktur dan sistem politik state (negara) yang belum berorientasi pada masyarakat kalangan bawah.

Partai-partai politik berlomba-lomba mengeksploitasi para nelayan tersebut dengan memasang berbagai atribut partai pada perahu/sampan mereka demi kepentingan elite politik itu, bukan kepentingan nelayan Politik negara belum berorientasi pada masyarakat bawah termasuk nelayan, karena terikat oleh berbagai kepentingan politik. Ketidakmampuan secara sosial, ekonomi dan politik tersebut menjadi ganjalan bagi mereka untuk bisa berdiri sama tinggi dan duduk sama rendah dengan saudara yang lain yang secara sosial dan ekonomi telah berhasil.

Tujuan utama penelitian ini adalah mengetahui hubungan motivasi kerja dengan perilaku nelayan pada usaha perikanan tangkap. Tujuan khususnya adalah: (1) Menemukan karakteristik (faktor internal dan eksternal) nelayan; (2) Menemukan motivasi kerja nelayan turut berperan serta dalam kegiatan ekonomi keluarga; (3) Menganalisis hubungan karakteristik dengan motivasi kerja nelayan dalam pemenuhan kebutuhan hidup keluarga; (4) Menganalisis hubungan karakteristik dengan perilaku nelayan dalam pemenuhan kebutuhan hidup keluarga. 


\section{Metode}

\section{Populasi dan Sampel}

Penelitian dilaksanakan di Kampung Nelayan Muara Angke, Kelurahan Pluit, Kecamatan Penjaringan, Jakarta Utara. Populasi penelitian ini adalah nelayan yang berada di Kampung Nelayan Muara Angke, Jakarta Utara. Jumlah nelayan sebanyak 1323 orang. Penarikan sampel dilakukan secara purposive random sampling. Peneliti mengambil suatu contoh acak, dari sebuah daftar anggota populasi yang didapatkan dari Kantor RW 01 dan RW 11, Kelurahan Pluit, Kecamatan Penjaringan, Muara Angke, Jakarta Utara. Jumlah responden adalah 100 orang. Penelitian dilaksanakan dari bulan November 2005 sampai dengan bulan Januari 2005.

\section{$\underline{\text { Desain }}$}

Penelitian terdiri dari tiga peubah bebas yaitu $\left(\mathrm{X}_{1}\right)$ adalah faktor internal serta faktor eksternal nelayan $\left(\mathrm{X}_{2}\right)$ dan $\left(\mathrm{X}_{3}\right)$ adalah motivasi kerja nelayan dan peubah tidak bebasnya (Y) adalah perilaku nelayan.

\section{$\underline{\text { Analisis Data }}$}

Data faktor individu dianalisis dengan menggunakan distribusi frekuensi, dan nilai tengah. Motivasi kerja nelayan dianalisis dengan angka berjenjang. Untuk mengetahui hubungan antar peubah dilakukan analisis hubungan dengan koefisien korelasi Spearman.

\section{Hasil dan Pembahasan}

Rataan umur responden adalah 30 tahun dengan kisaran umurnya antara 23- 39 tahun. Bila dipandang dari usia produktif, maka dapat dikatakan bahwa usia nelayan tergolong usia muda dan produktif, berarti nelayan memiliki kemampuan fisik yang baik. Kondisi fisik yang baik membuat nelayan dapat melakukan kegiatan secara optimal dan mampu mengembangkan diri dengan mengutamakan keberhasilan demi kesejahteraan keluarganya, khususnya untuk memenuhi kebutuhan anak.

Pendidikan formal responden antara lulus Sekolah Dasar (SD) sampai dengan Lulus Sekolah Menengah Pertama (SMP). Orang tua berpendapat bahwa menangkap ikan tidak perlu menempuh pendidikan yang tinggi. Alih pengetahuan dilakukan dengan cara memberi kesempatan kepada anak lakilaki yang masih duduk di bangku sekolah (1214 tahun keatas) dan dipandang sudah waktunya mengenal kehidupan laut, maksud keikutsertaan anak laki-laki melaut agar selalu ada anggota keluarga yang melanjutkan usaha orang tuanya sekalipun hanya sebagai pekerja nelayan.

Rataan jumlah tanggungan keluarga nelayan adalah dua orang. Adapun rataan pendapatan nelayan dengan rata-rata $\mathrm{Rp}$. 647.980.

Berdasarkan hasil penelitian, sebesar $84 \%$ responden menyatakan cukup tersedia informasi tentang perikanan. Kersediaan informasi berkaitan dengan: (1) jumlah informasi tentang perikanan masih dirasakan kurang oleh nelayan, (2) informasi yang ada hanya seputar surat izin melaut, padahal informasi yang dibutuhkan nelayan adalah tentang cara menjaga mutu hasil produksi tangkapan, dan informasi tentang harga ikan dipasaran.

Hasil analisis menunjukkan bahwa sebesar $68 \%$ responden menyatakan cukup mudah dalam mengakses informasi perikanan. Hasil wawancara terhadap tokoh-tokoh masyarakat, akses terhadap informasi dipengaruhi oleh: (1) nelayan mendapatkan informasi tentang perikanan terbanyak berasal dari nelayan satu kepada nelayan yang lain (dari mulut ke mulut). Nelayan menerima informasi melalui komunikasi langsung tanpa adanya medium khusus. Pesan yang ada disampaikan dari mulut ke mulut. Sistem ini dari segi pembiayaan cukup efesien dan efektif bagi nelayan di Muara Angke; (2) nelayan juga mendapatkan informasi berasal dari penyuluh, nelayan merasa materi yang disampaikan penyuluh mudah dimengerti 
tetapi nelayan hanya sebagai penerima informasi pasif, artinya hanya menerima informasi yang masuk ke dalam sistem sosialnya, dan kurang mencari informasi yang mereka butuhkan untuk meningkatkan usahanya.

Sebesar $80 \%$ responden menyatakan cukup sering mencari informasi perikanan di luar sistem sosialnya. Intensitas responden mencari informasi di dalam sistem sosialnya, menyebabkan nelayan bersifat lokalit. Sifat lokalit disebabkan nelayan menggantungkan hidupnya kepada juragan (pemilik kapal). Ketergantungan ini disebabkan jumlah pemilik kapal lebih sedikit dari pada nelayan yang membutuhkan pekerjaan.

Hasil analisis menunjukkan bahwa $80 \%$ responden menyatakan jarang mengikuti penyuluhan. Penyebab nelayan jarang mengikuti penyuluhan adalah: (1) responden kesehariannya berada di laut, (2) responden merasa materi yang disampaikan penyuluh hanya untuk orang-orang tertentu saja.

Sebesar $89 \%$ responden cukup memperhatikan permintaan pasar. Permintaan pasar tidak selalu terpenuhi disebabkan: (1) tidak adanya kepastian harga yang tetap dari ikan-ikan yang di tangkap, (2) ikan yang di peroleh tidak selamanya akan mereka peroleh tergantung dari musim ikan.

Sebesar $94 \%$ responden cukup mendapat kemudahan fasilitas. Nelayan beranggapan bahwa kapal motor/perahu dan alat tangkap yang mereka gunakan tidak ubahnya seperti rumah tangga sewaktu berada di darat, disebut pekarangan. Pekarangan yang dimaksudkan sebagai tempat untuk mendapatkan sumber kehidupan maka sebagaimana layaknya pekarangan, semua peralatan yang ada di atas kapal di pelihara dan dijaga keamanannya yang dapat memberikan kehidupan bagi pemilik dan penggunanya.
Menemukan Motivasi Anggota Rumahtangga

Nelayan Turut Berperan Serta dalam

Kegiatan Ekonomi Keluarga.

Motivasi Intrinsik. Hasil penelitian menunjukkan sebagian besar (82\%) responden merasa cukup termotivasi oleh kebutuhan dasar, seperti: makan, minum, pakaian, perumahan dan kesehatan.

Hasil penelitian menunjukkan sebagian besar (68\%) responden merasa cukup termotivasi oleh kebutuhan rasa aman/keselamatan, seperti: menabung, dan asuransi.

Responden cukup termotivasi oleh alasan kebutuhan sosial (relatedness), yaitu kebutuhan untuk bermasyarakat dan bergaul dengan sesama anggota sistem sosial yang lain $(88 \%)$. Data ini menunjukkan kebutuhan berafiliasi dan saling menyanyangi sesama anggota masyarakat yang cukup mendorong nelayan.

Mengenai aspek kebutuhan akan penghargaan (growth need), terdapat $(81 \%)$ responden yang merasa cukup termotivasi oleh kebutuhan penghargaan. Data ini menunjukkan kebutuhan berkembang cukup mendorong nelayan untuk maju, tetapi kebutuhan akan penghargaan ini perlu ditingkatkan untuk mendorong nelayan menjadi nelayan yang maju.

Responden sebesar $86 \%$ memiliki keinginan untuk berprestasi yaitu meningkatkan usahanya lebih baik dari keadaan sekarang. Niat untuk selalu melakukan pekerjaan dengan giat dan bersungguh-sungguh, niat untuk selalu bekerja dengan mutu hasil kerja yang terbaik, dan niat untuk selalu mencapai tatanan kerja secara efisien dan efektif. Penelitian ini didukung pendapat Maslow (1987), bahwa masyarakat yang memiliki $n$-Ach tinggi akan menghasilkan wiraswasta yang lebih giat, dan akan menghasilkan pembangunan ekonomi lebih pesat. 
Motivasi Ekstrinsik. Motivasi ekstrinsik adalah dorongan yang berasal dari luar diri nelayan bersifat menekan, sehingga nelayan meningkatkan usahanya. Hasil penelitian diperoleh sebesar $(77 \%)$ merasa cukup termotivasi karena tekanan dari faktorfaktor di luar diri mereka. Hal-hal yang menekan nelayan, yaitu: (1) permintaan pasar yang cukup tinggi terhadap ikan-ikan tertentu bisa mencapai Rp. $50.000 / \mathrm{Kg}$, (2) peluang untuk memperoleh keuntungan yang cukup besar, (3) kemudahan memperoleh saprodi, (4) harga saprodi yang dapat terjangkau nelayan.

\section{$\underline{\text { Perilaku nelayan }}$}

Sebesar $89 \%$ responden cukup memanfaatkan pelabuhan perikanan. Nelayan belum memanfaatkan pelabuhan perikanan yang tersedia secara optimal karena nelayan berpendapat bahwa pelabuhan tempat untuk beristirahat.

Pada umumnya dapat dikatakan bahwa upah kerja dengan sistem bagi hasil merupakan bentuk hubungan kerja yang paling banyak dipakai di Indonesia. Sistem ini tidak hanya berlaku dalam usaha perikanan antara majikan pemilik unit penangkapan dan nelayan yang menjadi awak kapal (perahu), melainkan berlaku juga di antara pemilik tanah dan petani penggarap.

Tabel 1. Hubungan Faktor Internal dengan Motivasi Kerja Nelayan

\begin{tabular}{|c|c|c|c|c|c|c|}
\hline \multirow{3}{*}{$\begin{array}{c}\text { Faktor } \\
\text { Internal } \\
\text { Nelayan }\end{array}$} & \multicolumn{6}{|c|}{ Motivasi Kerja nelayan } \\
\hline & $\begin{array}{c}\text { Kebutuhan } \\
\text { dasar }\end{array}$ & $\begin{array}{l}\text { Kebutuhan } \\
\text { rasa aman }\end{array}$ & $\begin{array}{c}\text { Kebutuhan } \\
\text { sosial }\end{array}$ & $\begin{array}{c}\text { Kebutuhan akan } \\
\text { penghargaan }\end{array}$ & $\begin{array}{l}\text { Kebutuhan } \\
\text { berprestasi }\end{array}$ & $\begin{array}{l}\text { Motivasi } \\
\text { ekstrinsik }\end{array}$ \\
\hline & Nilai korelasi & Nilai korelasi & Nilai korelasi & Nilai korelasi & Nilai korelasi & Nilai korelasi \\
\hline Umur & 0,029 & $0,203 *$ & $0,206 *$ & $0,225 *$ & 0,177 & 0,084 \\
\hline $\begin{array}{l}\text { Pendidikan } \\
\text { formal }\end{array}$ & 0,012 & 0,086 & 0,021 & 0,019 & 0,145 & 0,055 \\
\hline $\begin{array}{l}\text { Pengalaman } \\
\text { berusaha }\end{array}$ & 0,170 & 0,106 & 0,101 & 0,165 & $0,260 * *$ & $0,210 *$ \\
\hline $\begin{array}{l}\text { Jumlah } \\
\text { tanggungan } \\
\text { keluarga } \\
\end{array}$ & 0,063 & 0,107 & 0,039 & $-0,003$ & $-0,199 *$ & $-0,104$ \\
\hline $\begin{array}{l}\text { Pendapatan } \\
\text { nelayan }\end{array}$ & 0,071 & 0,044 & 0,063 & 0,080 & 0,176 & 0,194 \\
\hline
\end{tabular}

Responden menyatakan terlibat dalam suatu kelompok sebesar (78\%). Hubungan kerjasama dalam kelompok terjadi karena keseharian nelayan berada pada kelompok yang sama yaitu kelompok sesama nelayan. Suka dan duka dijalani bersama. Kerjasama dalam kelompok di luar dari kelompok nelayan (kelompok di darat) masih rendah. Hal ini disebabkan karena nelayan berada di laut. Istri nelayan banyak terlibat pada kelompok yang berada di darat. Responden sebesar $67 \%$ telah menjadi anggota koperasi. Responden yang turut serta di koperasi sebagai upaya untuk menjaga harga ikan agar tetap sesuai dengan usaha mereka. Harga ikan masih dimonopoli oleh pedagang dan pemodal.

Hubungan Karakteristik dengan Motivasi Kerja Nelayan dalam Pemenuhan Kebutuhan Hidup Keluarga

Satu peubah yang berhubungan negatif sangat nyata dengan motivasi kerja nelayan, yakni jumlah tanggungan keluarga. Jumlah tanggungan keluarga nelayan dengan peubah motivasi kerja nelayan terdapat hubungan negatif nyata pada kebutuhan berprestasi, 
artinya semakin banyak jumlah tanggungan nelayan maka akan semakin sulit untuk berprestasi karena nelayan memusatkan diri pada tanggungan keluarga yang ada.

Ketersediaan informasi berhubungan sangat nyata dengan motivasi kerja nelayan pada kebutuhan dasar, kebutuhan bersosialisasi, dan kebutuhan akan penghargaan. Motivasi kerja nelayan meningkat terhadap ketersediaan informasi akan mempengaruhi pemenuhan hidup keluarga.
Akses terhadap informasi berhubungan sangat nyata dengan motivasi kerja nelayan pada kebutuhan rasa aman dan kebutuhan berkembang. Tingkat akses terhadap informasi. Hubungan antara tingkat ketersediaan informasi dan akses terhadap informasi bahwa informasi tentang usaha perikanan tersedia, tetapi nelayan tidak mengaksesnya. Informasi yang ada belum dirasa penting dan dibutuhkan oleh nelayan. Mereka merasa belum cukup terdorong untuk mengakses informasi karena nelayan beranggapan informasi tersebut tidak menghasilkan uang.

Tabel 2. Hubungan Faktor Eksternal dengan Motivasi Kerja Nelayan

\begin{tabular}{|c|c|c|c|c|c|c|}
\hline \multirow{3}{*}{ Faktor Eksternal Nelayan } & \multicolumn{6}{|c|}{ Motivasi Kerja nelayan } \\
\hline & $\begin{array}{l}\text { Kebutuhan } \\
\text { dasar }\end{array}$ & $\begin{array}{l}\text { Kebutuhan } \\
\text { rasa aman }\end{array}$ & $\begin{array}{l}\text { Kebutuhan } \\
\text { sosial }\end{array}$ & $\begin{array}{c}\text { Kebutuhan } \\
\text { akan penghargaan }\end{array}$ & $\begin{array}{l}\text { Kebutuhan } \\
\text { berprestasi }\end{array}$ & $\begin{array}{c}\text { Motivasi } \\
\text { Ekstrinsik }\end{array}$ \\
\hline & $\begin{array}{c}\text { Nilai } \\
\text { korelasi }\end{array}$ & $\begin{array}{c}\text { Nilai } \\
\text { korelasi }\end{array}$ & $\begin{array}{c}\text { Nilai } \\
\text { korelasi }\end{array}$ & Nilai korelasi & $\begin{array}{c}\text { Nilai } \\
\text { korelasi }\end{array}$ & $\begin{array}{c}\text { Nilai } \\
\text { korelasi }\end{array}$ \\
\hline Ketersediaan informasi & $0,625 * *$ & 0,168 & $0,426 * *$ & $0,690 * *$ & 0,176 & 0,174 \\
\hline Akses terhadap informasi & 0,108 & $0,463 * *$ & 0,182 & $0,322 * *$ & $0,490 * *$ & 0,102 \\
\hline Kekosmopolitan & 0,157 & $-0,086$ & 0,046 & $0,332 * *$ & $0,663^{* *}$ & $\mathbf{0 , 5 5 8 * *}$ \\
\hline Intensitas penyuluhan & 0,157 & $-0,139$ & 0,046 & $0,278 * *$ & $0,735^{* * *}$ & $\mathbf{0 , 5 5 8 * *}$ \\
\hline Permintaan pasar & 0,111 & $\mathbf{0 , 3 0 7 * *}$ & 0,130 & $0,327 * *$ & 0,134 & 0.036 \\
\hline Kemudahan fasilitas & $0,509 * *$ & $-0,083$ & $0,295^{* *}$ & $0,256 * *$ & $-0,019$ & 0,062 \\
\hline
\end{tabular}

Akses terhadap informasi berhubungan sangat nyata pada kebutuhan berprestasi, artinya informasi yang nelayan peroleh akan mampu mewujudkan diri mereka kepada usaha yang lebih maju. Nelayan yang memiliki akses akan mampu untuk mengembangkan diri. Sifat kekosmopolitan nelayan berhubungan sangat nyata dengan motivasi kerja nelayan pada tingkat kebutuhan berkembang kebutuhan berprestasi dan motivasi ekstrinsik. Nelayan bergaul mencari informasi tentang usaha perikanan di luar sistem sosialnya akan meningkatkan usahanya dan nelayan akan mampu untuk mengemukakan pendapatnya sehingga usaha yang nelayan kerjakan akan membuahkan hasil, menjadi nelayan pemilik kapal (juragan). Intensitas penyuluhan berhubungan sangat nyata dengan motivasi kerja nelayan pada kebutuhan akan penghargaan, pada kebutuhan berprestasi dan pada motivasi ekstrinsik. Penyuluh merasa informasi yang disampaikan sangat diperlukan oleh nelayan dan sesuai dengan kebutuhan nelayan, 
sehingga nelayan sering untuk mengikuti kegiatan penyuluhan. Nelayan yang mengikuti penyuluhan secara teratur akan mampu mengembangkan diri dan usahanya menjadi lebih baik lagi.

Permintaan pasar berhubungan sangat nyata dengan motivasi kerja nelayan pada kebutuhan rasa aman dan pada kebutuhan akan penghargaan, semakin tinggi motivasi kerja nelayan untuk berusaha, maka akan meningkatkan orientasi nelayan pada pasar, perhatian nelayan pada harga, dan jumlah produksi.

Kemudahan fasilitas berhubungan sangat nyata dengan kebutuhan dasar, kebutuhan sosial dan kebutuhan akan penghargaan. Semakin lengkap fasilitas yang disediakan baik fasilitas untuk sehari-hari maupun fasilitas tangkapan ikan menyebabkan semakin tinggi pula motivasi kerja pada diri nelayan untuk memenuhi kebutuhan sandang, pangan, papan, bergaul antar sesama nelayan, dan mengemukakan pendapat.

Hubungan Karakteristik Internal dengan

Perilaku Nelayan dalam Pemenuhan

Kebutuhan Hidup Keluarga

Pengalaman berusaha berhubungan sangat nyata pada perilaku bagi hasil dan perilaku dalam berkoperasi. Hubungan kerja nelayan dan juragan yang bekerja hanya berpatokan pada rasa suka dan adanya sikap saling percaya, sehingga mereka tidak melakukan ikatan hubungan tersebut dalam bentuk tertulis. Karena faktor suka dan saling percaya ini, maka perasaan memegang peranan penting dalam hubungan antara keduanya.

Hubungan Karakteristik Eksternal dengan $\underline{\text { Perilaku Nelayan }}$

Permintaan pasar mempengaruhi perilaku nelayan. Permintaan pasar yang tinggi terhadap hasil tangkapan yang disertai dengan harga ikan yang sesuai dengan harga pasar.
Ketersediaan informasi berhubungan sangat nyata pada perilaku memanfaatkan pelabuhan perikanan dan perilaku bagi hasil. Hal ini disebabkan nelayan mengalami kendala, yaitu tidak adanya alternatif lain (bandingan harga) dengan penjual ikan yang lain dan mengalami kesulitan untuk memperhitungkan hasil tangkapan dalam bentuk uang. Nelayan hanya tahu jumlah kilogramnya pada setiap kali penjualan.

Akses terhadap informasi berhubungan nyata dengan perilaku nelayan memanfaatkan pelabuhan perikanan. Dermaga merupakan tempat persinggahan bagi para nelayan sepulang dari mereka melaut. Dermaga tempat untuk melakukan pendaratan, membersihkan kapal, memperbaiki alat tangkap, dan menjual hasil tangkapan dari sisa ikan yang mereka peroleh.

Kekosmopolitan berhubungan sangat nyata dengan perilaku bagi hasil, dan perilaku menjalin kerjasama dalam kelompok. Hal ini disebabkan nelayan yang bekerja membawa kapal atau motor milik juragan dan menangkap ikan berarti mempunyai hubungan kerja dengan juragan, dan sekaligus mempunyai keterikatan dalam hal perolehan ikan hasil tangkapannya.

Intensitas penyuluhan berhubungan sangat nyata dengan perilaku nelayan bagi hasil dan perilaku menjalin kerjasama dalam kelompok. Salah satu faktor penyebabnya adalah nelayan kurang merasakan manfaat penyuluhan terhadap informasi harga ikan karena sampai saat ini TPI dirasakan hanya sebagai tempat istirahat setelah beberapa hari melaut. Juga sebagai tempat menurunkan hasil tangkapan, membersihkan kapal dan tempat penjualan ikan dari juragan ke bakul.

Permintaan pasar berhubungan sangat nyata dengan perilaku nelayan memanfaatkan pelabuhan perikanan. Dengan perilaku nelayan bagi hasil, perilaku menjalin kerjasama dalam kelompok dan koperasi. Pemasaran di antara juragan, pemilik modal dengan sejumlah pedagang perantara. Proses ini merupakan kelanjutan dari norma-norma sosial ekonomis. Hubungan sosial antara 
kelompok penangkap ikan dengan kelompok pedagang ikan merupakan gambaran dari sistem sosial dimana lembaga tukar menukar (jasa dengan jasa atau jasa dengan uang) bertindak sebagai tali penghubung.

Kondisi seperti itu memberikan kesan adanya monopoli dari juragan yang bertindak sebagai pembeli yang menguasai pemasaran dan juga sebagai pemilik yang mempekerjakan nelayan dalam kegiatan produksi, dengan demikian hubungan antara juragan dengan anak buah (nelayan) masih melalui perantaraan juragan.

Kemudahan fasilitas berhubungan sangat nyata dengan perilaku bagi hasil. Hal ini disebabkan hubungan keluarga nelayan dengan keluarga juragan tidaklah terlalu dekat. Hubungan yang ada sebatas hubungan kenal dan menyangkut pinjaman. Tidak ada kewajiban atau keharusan untuk mengabdikan dirinya kepada keluarga juragan, walaupun hubungan antara suaminya dengan juragan sudah berlangsung lama.

Hubungan Motivasi Kerja dengan Perilaku Nelayan dalam Pemenuhan Kebutuhan Hidup Keluarga

Motivasi kerja nelayan pada kebutuhan dasar berhubungan sangat nyata dengan perilaku nelayan dalam bagi hasil. Hal ini berarti semakin tinggi motivasi nelayan pada kebutuhan dasar maka perilaku nelayan untuk bagi hasil semakin tinggi.

Motivasi kerja nelayan pada kebutuhan rasa aman berhubungan sangat nyata dengan perilaku nelayan memanfaatkan pelabuhan perikanan. Artinya, semakin sering nelayan memanfaatkan pelabuhan perikanan, semakin tinggi pula motivasi kerja pada kebutuhan rasa aman, seperti menabung. Nelayan memanfaatkan pelabuhan perikanan sebagai buruh.

Motivasi kerja nelayan pada kebutuhan sosial berhubungan sangat nyata dengan perilaku bagi hasil. Hal ini disebabkan hubungan antara sesama nelayan, merupakan pelaku utama dalam kegiatan penangkapan.
Motivasi kerja nelayan pada kebutuhan akan penghargaan berhubungan sangat nyata dengan perilaku nelayan dalam bagi hasil, dan perilaku menjalin kerjasama dalam kelompok. Hal ini berarti semakin tinggi motivasi nelayan pada kebutuhan akan penghargaan, seperti: mengemukakan pendapat akan sangat mempengaruhi perilaku nelayan untuk bagi hasil dan terlibat dalam kelompok.

Motivasi kerja nelayan pada kebutuhan berprestasi berhubungan sangat nyata dengan perilaku nelayan pada bagi hasil dan menjalin kerja sama dalam kelompok. Ini berarti semakin tinggi motivasi nelayan pada kebutuhan berprestasi, maka perilaku nelayan bagi hasil dan bekerja sama dapat ditingkatkan. Wadah berhimpun bagi para nelayan juga sudah ada yang dikenal dengan sebutan Kelompok Tani Nelayan Andalan (KTNA) yang bertujuan untuk memudahkan dalam memberi pembinaan kepada nelayan guna peningkatan taraf hidup nelayan. Lembaga ini belum begitu efektif dan maksimal di manfaatkan nelayan sebagai wadah berhimpun tetapi masih banyak nelayan yang belum mengetahui keberadaan dan fungsi lembaga ini.

Motivasi ekstrinsik berhubungan sangat nyata pada perilaku bagi hasil. Artinya, semakin tinggi motivasi nelayan dari luar dirinya akan semakin tinggi perilakunya pada bagi hasil. Nelayan mengharapkan bagi hasil yang adil karena semakin banyak kebutuhan yang harus dipenuhi, seperti kenaikan BBM akan mengurangi pendapatan nelayan sehingga nelayan harus menanggung biaya perjalanan selama menangkap ikan sedangkan hasil yang nelayan peroleh tidaklah sepadan dengan tenaga yang dikeluarkan.

\section{Kesimpulan} penelitian ini, yaitu:

Dari keseluruhan pembahasan

(1) Karakteristik (faktor internal dan eksternal) nelayan tergolong baik dan mendukung untuk memenuhi kebutuhan hidup keluarga. 
(2) Kebutuhan hidup keluarga melahirkan motivasi. Motivasi kerja nelayan cenderung kepada kebutuhan dasar.

(3) Karakteristik (faktor internal dan eksternal) nelayan berpengaruh terhadap motivasi kerja nelayan untuk pemenuhan kebutuhan hidup keluarga.

(4) Hubungan karakteristik nelayan dengan perilaku nelayan didasarkan atas adanya kebutuhan untuk memenuhi kebutuhan hidup keluarga dan didasarkan oleh rasa suka antara nelayan dan juragan.

(5) Hubungan antara motivasi kerja dengan perilaku nelayan termasuk kategori baik, semakin tinggi motivasi kerja nelayan maka perilaku nelayan semakin baik untuk memenuhi kebutuhan hidup keluarga.

\section{Rujukan:}

Conyer D. 1994. Perencanaan Sosial di Dunia Ketiga. Yogyakarta: Gadjah Mada University Press.

Kusnadi. 2004. "Diversifikasi Pekerjaan di Kalangan Nelayan". Prisma No. 7. JuliAgustus. Jakarta: LP3ES.

Nikijuluw V. P. 2002. Rezim Pengelolaan Sumberdaya Perikanan. Jakarta: Pusat Pemberdayaan dan Pembangunan Regional (P3R).

Setyohadi. 1997. "Peran Ilmu Pengetahuan dan Teknologi dalam Pemberdayaan Sumberdaya Perikanan sebagai Perwujudan Konsepsi Benua Maritim Indonesia. Pusat Penelitian dan Pengembangan Perikanan." Jakarta: Prosiding Simposium Perikanan Indonesia II. 